\title{
ВЕЩИЙ ОЛЕГ В ИСТОРИИ КИЕВСКОЙ РУСИ
}

\section{PROPHETIC OLEG IN THE HISTORY OF KIEVAN RUS}

A. Polyakov

Summary: The article deals with the controversial issue of the role of Prince Oleg in the formation of the ancient Russian state. The author comes to the conclusion that none of the events described by the chroniclers related to the name of Oleg is confirmed in other sources. All of them are the result of book constructions based on biblical and folklore stories. The image of the prophetic prince, which was drawn by the author of the "Tale of Bygone Years", is the fruit of the creativity of an Old Russian scribe, and not a historical person.

Keywords: Oleg, "The Tale of bygone years", the Novgorod First Chronicle, the campaign, Igor, the contract.

\author{
Поляков Александр Николаевич \\ К.и.н., дочент, Оренбургский государственный \\ университет \\ polyakov150@mail.ru
}

Аннотация: В статье рассматривается спорный вопрос о роли князя Олега в образовании древнерусского государства. Автор приходит к выводу, что ни одно из описанных летописцами событий, связанных с именем Олега, не находит подтверждения в других источниках. Все они являются результатом книжных построений, основанных на библейских и фольклорных сюжетах. 0браз вещего князя, который был нарисован автором «Повести временных лет» — плод творчества древнерусского книжника, а не историческое лицо.

Ключевые слова: Олег, «Повесть временных лет», Новгородская Первая летопись, поход, Игорь, договор.

$[15$, с. 221]. Сомнений в самом факте похода (и слияния) ни у кого не было. В «Очерках истории СССР», обобщивших представления советских историков по этому вопросу, подчёркивалось: «Независимо от того, когда и как произошло объединение двух центров - Киева и Новгорода - самое объединение - факт несомненный и по своим результатам чрезвычайно важный» $[18$, с. 80]. А.П. Новосельцев называет Олега «первым достоверным государственным деятелем нашей истории» [17, с. 3]. Он отмечает, что «в нашей историографии именно Олег считался первым правителем Древнерусского государства, образовавшегося после объединения русского севера, откуда этот правитель пришёл, с югом, главный город которого (Киев) он сделал столицей державы» [17, с. 3]. Первым достоверным русским князем Олега считает и А.Л. Никитин: «... Олег выступает в ПВЛ первой фигурой, чье существование подтверждается датированным документом - договором, заключённым этим князем с греками 2 сентября 911 (6420 «сентябрьского») года» [16, с. 170]. Н.Ф. Котляр называет утверждение в Киеве Олега «решающим шагом на пути государственного строительства в Восточной Европе» [11, с. 48].

Сведения о Вещем Олеге в древнерусских источниках противоречивы. Новгородская Первая летопись младшего извода, в которой, согласно распространённому мнению, отразился Начальный летописный свод (середина 90-х годов XI века), называет Олега воеводой Игоря. «Повесть временных лет» (начало XII века) представляет его князем, родственником Рюрика, действующим от имени Игоря. В Иоакимовской летописи, пересказанной В.Н. Татищевым, Олег называется шурином Рюрика, князем «урманским» [26, с. 56]. 
Олег появляется в нашей истории после смерти Рюрика. В Новгородской первой летописи это событие в некотором роде затушёвано и не датировано. Вернее, сообщение об Олеге стоит под тем же годом (854 г.), что и рассказ о Кие, Щеке и Хориве, хазарской дани и призвании Рюрика с варягами: «И роди сынъ, и нарече имя ему Игорь. И възрастъшю же ему, Игорю, и бысть храборъ и мудръ. И бысть у него воевода, именемъ Олегъ, муж мудръ и храборъ» [22, с. 107]. В «Повести временных лет» содержатся несколько иные сведения. Под 879 годом здесь говорится: «Оумершю Рюрикови предасть кня[же]нье свое Олгови от рада [рода] имъ суща въдвавъ сынъ свои на руче Игоря, бысть бо детескъ вельми» [21, стб. 22]. В Новгородской летописи следом идёт рассказ о походе Игоря с воеводой Олегом на Киев, где сидели Аскольд и Дир. Об этом же под 882 годом сообщает и «Повесть временных лет». Только поход здесь возглавляет не Игорь, а Олег (Игорь в «Повести» в то время ещё ребёнок). Что касается содержательной части рассказов - в основном она совпадает. Согласно «Повести», Олег, собрав большое войско (варягов, чудь, словен, мерю, весь и кривичей), и отправившись на Киев, взял по пути Смоленск и Любеч, посадил там своих мужей, а, добравшись до киевских гор, спрятал своих воинов в ладьях. Объявив себя купцом, он пригласил Аскольда и Дира на переговоры, назвал их самозванцами и убил. Далее в «Повести» помещена знаменитая фраза Олега, которая в Новгородской летописи отсутствует. Олег будто бы сказал: «се буди м[a] ти градомъ рускими». Последующий текст - [u] беша оу него Варязи и Словени и прочи прозвашася Русью» [21, стб. 23] - в обеих летописях есть. Только в первой под местоимением «оу него» имеется в виду Игорь, а во второй - Олег.

Оба рассказа вызывают большие сомнения. Датировка событий (854 или 882 год) не соответствует действительности и это общеизвестно. Обе даты условны. Под 854 годом в Новгородской летописи, очевидно, собраны разновременные события. Здесь и основание Киева, и призвание варягов, и поход на Киев. Вряд ли можно допустить, что все они произошли в один год. Происхождение второй даты тоже не понятно, и сама она ничем не подтверждена. Никакой другой источник, современный «Повести» или более древний, о походе на Киев Олега (как и Игоря) не сообщает. Учитывая то, что летописец отделён от данного события двумя и более сотнями лет, и не мог писать об этом со слова очевидцев, ссылаться на сообщение о походе, как на реальный факт, нельзя. Всё, что здесь делает Олег или Игорь не выходит за рамки стереотипных действий, которые совершали князья во времена летописцев, то есть В XI и XII веках. А то, что можно здесь отнести к оригинальным фактам, не подтверждается не только другими письменными источниками, но и археологическими. Более того, последние прямо им противоречат. Ни Новгорода (где якобы княжил Рюрик, а потом Игорь и Олег), ни Ростова, Полоцка и Белооозера (где Рюрик разместил своих людей), ни Смоленска и Любеча (где Олег оставил своих мужей) в IX веке не существовало. На месте Новгорода вообще нет слоёв IX века. В.Л. Янин, после многолетних раскопок города, пришёл к выводу, что до середины X века на его месте находился ряд боярских хуторов, отделённых друг от друга пустыми пространствами. Облик города, по его мнению, Новгород приобрёл «только в середине X столетия, когда повсеместно началось сооружение уличных деревянных мостовых, возникла усадебная уличная планировка, появились дренажи» [28, с. 277]. Древнейшие славянские напластования Полоцка также датируются X веком. Детинец в устье реки Полоты сооружается во второй половине X века [6, с. 79]. Городские черты Полоцк приобретает в конце $\mathrm{X}$ - начале XI веков, когда распространяется дворово-уличная застройка и строятся мостовые. Белоозеро даже в X веке оставался посёлком веси. Древнерусским городом он становится только в XII столетии [6, с. 89]. Первые укрепления Смоленска, датируются археологами рубежом XI - XII веков. Заселение подола относится к середине XI века [6, с. 81, 82]. Как известно, древнерусскому Смоленску предшествовало Гнёздово X - XI веков - открытое торгово-ремесленное поселение с многонациональным населением. Однако Гнёздово вряд ли можно считать первоначальным Смоленском, как это делают некоторые исследователи. Это было поселение, тесно связанное с международной торговлей. Оно представляло собой ни что иное, как торговое место, факторию и прямого отношения к будущему Смоленску не имело [4, с. 49]. Ростов по археологическим данным появляется не ранее XI века. Ему предшествует Сарское городище IX - X веков [7, с. 33-48, 59], но его, как и Гнёздово относительно Смоленска, нельзя признать первоначальным Ростовом. Укрепления Любеча были построены также в XI веке [6, с. 95].

Согласно «Повести временных лет», закрепившись в Киеве, Олег стал принуждать платить дань окрестные славянские племена - древлян (883 г.), северян (884 г.), радимичей (885 г.). Затем сведения о его деятельности прерываются сообщениями из истории Византии (887 г.), сказанием о начале славянской письменности (898 г.) и рассказом о походе угров на болгар (902 г.). Под 903 годом в летописи помещено краткое сообщение об Игоре, который, как здесь говорится, повзрослев, сопровождал Олега везде и слушал его, а потом женился на Ольге, тоже, по всей видимости, по его настоянию. Достоверность этих сведений (как и предыдущих), по всей видимости, невелика. Происхождение их непонятно, а данные ничем не подтверждены. «Похоже, перечисление войн и походов Олега на окрестные племена, - пишет А.Л. Никитин, — нужно было ... лишь для того, чтобы потом послать все эти этносы с Олегом на Царьград, поскольку ни одно из этих событий не имеет своего внутреннего содержания и цели» [16, с. 174]. 
Главным событием княжения Олега является поход на греков, который датируется в Новгородской Первой летописи 922 годом, а в «Повести временных лет» 907м. Поход Олега 907 года с договорными статьями и следующий за ним договор 911 года, являются предметом спора. Это одна из тем, которая пользуется постоянным вниманием. Историография вопроса обширна. Среди авторов, посвятивших ему свои труды, известные русские исследователи: Н.А. Лавровский, В.И. Сергеевич, А.А. Шахматов, В.М. Истрин, С.П. Обнорский, Д.С. Лихачёв, А.А. Зимин, А.Н. Сахаров, С.М. Каштанов и многие другие.

Кроме русских летописей о походе ни один источник не сообщает. Ни западные хронисты, ни византийские авторы (писавшие о походе 860-го года или 941-го), ни восточные учёные о нём ничего не знают. Это важное обстоятельство, которое не позволяет полностью доверять данному сообщению летописей, а при определённых условиях - верить ему вообще.

Согласно «Повести временных лет», князь Олег вышел из Киева, собрав большое войско, в которое включил варягов, чудь, мерю и всех восточных славян (полян, северян, словен, кривичей, древлян, радимичей, вятичей, хорватов, дулебов, тиверцев). Войско двигалось на конях и 2000 кораблях. С учётом того, что в каждом корабле находилось по 40 мужей, число ладейного войска (не считая конного) должно было насчитывать 80 тысяч человек. Подойдя к Царьграду, Олег стал разорять окрестности, многих убил, разграбил и пожёг множество церквей, замучил и утопил большое количество пленных. После этого он приказал поставить корабли на колёса и направил свою армаду на штурм города. Греки, испугавшись, запросили мира. Вынесли ему вино и пищу, но Олег пить отказался, поскольку знал, что вино отравлено. Изумившись этому, греки будто бы сказали: «Это не Олег, но святой Дмитрий, посланный на нас Богом» [20, с. 153]. Олег потребовал от греков дань на каждого человека по 12 гривен. Но посчитал только тех, которые приплыли на кораблях, забыв о коннице: «И заповъда Олегъ дань даяти на 2000 корабль, по 12 гривенъ на человъкъ, а в корабли по 40 мужь» [20, с. 17]. Греки согласились. Тогда Олег отошёл от города и начал переговоры о мире. Далее летописец приводит данные о содержании заключённого договора и процедуры присяги обеих сторон. Поклявшись оружием, Перуном и Волосом беречь установленный мир, Олег приказал сшить паруса - руси «nаволочиты», а славянам «кропиньныя», которые ветер разодрал, как только они были подняты. Олег повесил свой щит на вратах Царьграда «показуа побгду» и отправился домой, неся золото, паволоки, плоды, вино и всякое узорочье.

Исследователи не выработали единой точки зрения по этому вопросу. Одна часть авторов не верит летопис- цу, сомневаясь, если не в самом факте похода, то в содержании рассказа, другая - полностью ему доверяет. Первая группа исследователей ссылается на то, что рассказ переполнен сомнительными чертами. Среди наиболее очевидных - указание на конницу среди участников похода, описание бесчинств Олегова войска в окрестностях Царьграда, гривны в качестве дани, поставленные на колёса корабли и щит, повешенный на ворота столицы Империи.

Многим исследователям огромное войско в 2 тысячи кораблей и минимум 80 тысяч воинов, связанная с ним громадная дань в 960 тысяч гривен (8 тысяч пудов серебра) кажется эпическим преувеличением, свойственное фольклору [20, с. 416]. Г.М. Барац считает, что количество кораблей кратно увеличилось, благодаря ошибкам переписчиков. На деле, по его мнению, в летописи первоначально стояло не 2000, а 200 кораблей. Причём, число это было взято из описания похода на Царьград 860 года [1, с. 9]. В Новгородской Первой летописи действительно говорится не о 2000, а о 200 (точнее 100 и 200) кораблях $[22$, с. 108$]$.

Выражение «на конех и на кораблех» - шаблон, который русские летописцы часто используют при описании различных походов. Восходит он, вероятно, к библейской традиции. В данном случае о выдумке летописца говорит то, что конница, упомянутая в начале рассказа, впоследствии совершенно бесследно исчезает, не получает дань и не возвращается домой.

Рассказ о бесчинствах в окрестностях Царьграда является цитатой из описания похода Игоря 941 года, в свою очередь восходящего к византийскому источнику - Хронике Георгия Амартола [3, с. 158].

Гривны в качестве единицы дани отражают денежную систему времён летописца, а не Олега. Ниже в договорах 911 и 945 годов они уже не упоминаются. В качестве платёжных средств там указываются только византийские золотники (солиды, номисмы), литры (византийский фунт, аналог римской либры) и паволоки (драгоценные ткани).

Штурм города на кораблях, поставленных на колёса, с военной точки зрения неэффективен и мало кого может напугать. Искать практический смысл в этом манёвре - будто бы под образом кораблей на колёсах скрывается вполне обыденное перетаскивание кораблей волоком - не имеет смысла. Летописец рассказывает не о том, что Олег волоком тащил корабли (занятие это нелёгкое и не производит впечатления), а о демонстрации невиданной силы, умении творить чудеса. Это выдаёт в рассказе легендарную основу. Лучше всего сюжет о флоте на колёсах объясняется пророчеством, ставшим известным после падения Византии в середине XV века. 
«... Согласно сообщению участника взятия Константинополя, турка Коджиа-Еффенди, - пишет И.Н. Данилевский, - существовало предание: Византия будет завоёвана, когда неприятельский флот “переплывёт сушу"» [3, с. 157]. Не исключено, что наш летописец воспользовался именно этим преданием для описания триумфа Олега, намекая таким способом на символическое падение Второго Рима. Существуют и другие близкие летописному рассказы, носящие фольклорный характер. Например, А.И. Лященко, обращает внимание на сообщение Саксона Грамматика, в котором Регнер (Рагнар) Лодброг, легендарный король Дании (VIII-IX вв.) приказывает поставить свои лодки на колёса и, водрузив их на повозки, с бешеной скоростью устремляется на врагов [14, с. 283]. Правда, сходство здесь не буквальное. Регнер, согласно сообщению датского хрониста, использовал этот приём не для устрашения противника, а в качестве тарана, стремясь разрушить боевой строй рутенов, с которыми он воевал: «Увидев их бесчисленное войско, Регнер засомневался, хватит ли [его собственных] сил [для того, чтобы одолеть противника], и приказал установить либо на колёса, либо на повозки 'бронзовых коней' и [во время сражения] изо всех сил вкатывать их в самую гущу вражеских войск. Они столь успешно опрокидывали вражеский строй, что казалось, будто бы эти махины, чья неудержимая масса сокрушала всё, что стояло у неё на пути, приблизили победу даже сильнее, чем само войско» $[25$, с. 330$]$.

Что касается щита, повешенного на городские ворота, обычай такой у славян и на Руси не известен. Ссылки на болгарский или скандинавский опыт здесь вряд ли приемлем. Русский книжник описывает действия вещего князя как знак победы, а не предложения мира, защиты или доброй воли. Акция, предпринятая Олегом, имеет прямую аналогию в библейском пророчестве Иезекииля. Описывая торговый город Тир и его могущество, пророк в частности говорит: «Перс и Лидиянин и Ливиец находились в войске твоём и были у тебя ратниками, вешали на тебе щит и шлем; они придавали тебе величие (Выделено мною. - А.П.)» (Иез. 27:10). Здесь же, кстати, отмечаются «узорчатые полотна из Египта», из которых шились паруса (Иез. 27:7). Это указание на богатство города, проявляющееся в безумном расточительстве. Подобный текст и с тем же смыслом находим в рассказе о возвращении Олега после заключения мира (о паволочитых и кропинных, т.е. дорогих златотканых и шёлковых парусах).

Главным основанием доверять автору «Повести» и наделять летописного Олега чертами исторической личности служит договор 911 года. Н.П. Ламбин, посвятивший вопросу достоверности сообщения о походе 907 года особый труд, считал этот довод настолько весомым, что его «невозможно будет сдвинуть с места» [13, с. 126]. Договором Олега он даже обосновывал реальность призвания варягов во главе с Рюриком [13, с. 123]. С.В. Юшков высоко оценил его заслуги: «После ... работы Ламбина, доказавшего в основном историчность похода князя Олега на Византию в 907 г., последние сомнения в подлинности договоров должны были отпасть» $[27$, с. 80]. Приём оригинальный: достоверность похода доказывается подлинностью договора, а достоверность договора реальностью похода.

Действительно, договор заключён от имени Олега и как будто свидетельствует о том, что поход, который привёл к его подписанию, существовал. Такое мнение вполне оправдано, если полагать, что летописец просто скопировал попавшие ему в руки документы. Однако хорошо известно, что это не так. Практически все исследователи подчёркивают, что договоры являются пересказами имевшихся в распоряжении летописца копий. С.М. Каштанов, изучавший формуляры договоров, утверждает, что акты, включённые в «Повесть», не являются точным воспроизведением императорских хрисовулов $[8$, c. 9, 12]. Во всех случаях он находит следы правок со стороны русского летописца, испортивших протокольную запись оригинала. Среди такого рода «исправлений» можно назвать добавление к титулу русского князя слова «великий» (а в договоре 911 г. ещё и «светлый»). Первое, как и второе, вряд ли могло быть в подлиннике. Официальный титул правителя Руси в греческой политической терминологии звучал как «архонт России», что переводится как «князь Руси», «князь русский» (так в договоре 971 года: «Азъ Святославъ, князь руский, яко же кляхъся ...»[20, с. 34]). Странно выглядит интитуляция договора 911 года. Здесь язычник Олег не только позволяет себе называться «наша светлость» (что, как считает С.М. Каштанов, соответствует переводу с греческого титула префекта претория [8, с. 12]), но и позиционирует себя как правитель-христианин. «Наша свљтлость, обращается он к византийскому императору, - боле инґхъ хотящихъ же о Бозґ удгоржати и извгсттити такую любовь (выделено мною. - А.П.), бывшюю межю хрестияны и русью многажды, право судихом, не точью простословесенъ и писаниемь и клятвою твердою, клґншеся оружьемь своимъ, такую любовь извгостити и утвъьрдити по въьрг и по закону нашему» [20, с. 18]. Необычным является и то, что ранее речь в договоре шла от имени послов, а не князя. На это обратил внимание Г.М. Барац [1, с. 55]. Но ни в отношении русского князя, ни тем более послов, этот титул никогда не употреблялся. Более того, титул «наша светлость» известен в отношении византийских василевсов. Во всяком случае, в цитате слов императора Константина IX Мономаха, приводимой И.П. Медведевым, он себя так и называет: «...вы не станете придерживаться только мёртвой буквы книг, - обращается он к студентам вновь открытого им юридического училища, - но и услышите живой голос законов, которому наша светлость (выделено мною. - А.П.) позволила раздаться среди вас, закрыв, с 
одной стороны, все боковые двери и, с другой - широко распахнув одну-единственную дверь - имперскую ...» $[12$, с. 240$]$.

Настораживает и существенная разница в оформлении посольской миссии во всех представленных в «Повести» соглашениях. В договоре 911 г. послы представляют только русского князя, в грамоте 945 года князя, его жену, сына, родственников и киевскую знать (перечислено, какой посол кого именно представляет). В договоре 971 г. имён послов нет вообще, там упомянут только князь Святослав. Вероятно, в условиях похода, когда переговоры вёл сам князь, это и не требовалось. Отправлять послов имело смысл, только если он был в Киеве и в переговорах не участвовал. Если так, в договоре 907 года мы вправе ожидать отсутствие каких-либо послов. Олег, как и Святослав должен был сам вести переговоры и заключать договор от своего имени и от первого лица. В договоре же 907 г., как и 911-го Олег везде указан в 3-м лице (кроме «нашей светлости»).

Налицо довольно существенная редакторская правка со стороны летописца. Быть уверенным в этой связи, что договор был заключён Олегом нельзя. Летописец мог просто вписать его имя, как это он сделал в сообщении о походе на Киев 882 года, поменяв Игоря, который руководил походом, согласно Начальной летописи, на Олега. Это означает, что надёжных свидетельств о существовании грандиозного похода 907 года нет. А те, что есть, вызывают большое и справедливое недоверие к нему. Состав участников (наличие, а потом исчезновение конницы), характер боевых действий (разграбление окрестностей, взятое из описания похода Игоря 941 г.), ключевые события похода (постановка кораблей на колёса, дань гривнами, водружение щита на ворота), являясь результатом книжных построений летописца, а не отражением реальных фактов, ставят под вопрос и сам поход.

И.Н. Данилевский и Д.А. Добровольский обратили внимание на то, что описание войска Олега с подробным перечислением племён и народов, напоминает пророчество Иезекииля. «и съберу тя и всю силу твою, коня и конники облъчены въ броня вся, съборъ многъ, шлемы и мечаи щиты вся имуща. Вси тии персе и мури, и лиди, и ливиесъ, и футть с ними, и вси сии щиты и шлемы имуще. Гомерь и вси иже о немъ, домъ трегамань и вся оутвержения его, и страны многи с нимъ» (Иез. 38:4-6). Д.А. Добровольский считает, что «навязчивость, с которой киево-печерские книжники перечисляли племена, принимавшие участие в походах Олега и Игоря, заставляет предположить, что составители начальной летописи не только знали и принимали популярное среди определенной части византийских мыслителей отождествление Руси и страны Гога, но и были готовы внести в строительство подобного образа собственную лепту» [5, с. 152].
Рассказ о походе действительно производит впечатление сказания или мифа, а сам Олег - мифического героя, действия которого направлены на реализацию пророчества Иезекииля. Олег, как и Гог, идёт на землю избранного народа с огромным войском «из пределов севера», ведя с собою множество народов; отнимает имущество, захватывает серебро и золото. На характер рассказа и его образный ряд могло повлиять и другое пророчество, сказанное Даниилом: «Под конец же времени сразится с ним царь южный, и царь северный устремится как буря на него с колесницами, всадниками и многочисленными кораблями, и нападёт на области, наводнит их, и пройдет через них. И войдет он в прекраснейшую из земель, и многие области пострадают... И завладеет он сокровищами золота и серебра и разными драгоценностями Египта ... и раскинет он царские шатры свои между морем и горою преславного святилища; но придёт к своему концу, и никто не поможет ему» (Дан. 11:40-45).

Возможно, не случайно, следующий за описанием похода текст в «Повести временных лет» рассказывает именно о гибели вещего князя. Находится он в летописи под 912 годом, как и договор. «Повесть временных лет» представляет одну из версий смерти Олега от укуса змеи, которая выползла из черепа его любимого коня. Другие варианты содержатся в Новгородской Первой летописи и Архангелогородском летописце.

Согласно «Повести временных лет», Олег после заключения договора жил в Киеве, имея мир со всеми странами. Когда наступила осень, он вспомнил отвергнутого им любимого коня, которого когда-то приказал кормить и беречь. Князь отказался от него, потому что кудесник предсказал ему смерть от коня, на котором он ездил. Случилось это, по словам летописца, за несколько лет до похода на греков. А через четыре года после похода он вспомнил про коня, но оказалось, что тот давно умер. Олег посмеялся над волхвом-предсказателем. «Конь умер, а я жив» - сказал он. Приехав на место, где лежали кости любимого коня, Олег наступил ногой на его череп, оттуда выползла змея и укусила его в ногу. Олег разболелся и умер. Похоронили князя на горе Щековице, где, по словам автора «Повести», есть могила Олегова и поныне.

В Новгородской Первой летописи рассказ об этом очень краток. Здесь сообщается, что Олег из Киева после похода на греков уехал в Новгород, а потом в Ладогу, где и умер (как и в «Повести временных лет» от укуса змеи). И «есть могыла его в Ладозе» [22, с. 109] - говорится в летописи. Архангелогородский летописец (Устюжский летописный свод) сообщает, что Олег умер «перешед море», хотя после описания предсказания и смерти от змеи, как и новгородская летопись, утверждает, что могила его находится в Ладоге [23, с. 58]. 
Исследователи давно обратили внимание на сходство летописного рассказа с древним скандинавским сказанием о конунге Одде Стреле, записанным в XIII веке [24, с. 259-266]. Согласно саге, Одд происходил из северной провинции Норвегии. Вещунья (вёльва) предсказала ему, что проживёт он 100 (300) зим, будет странствовать по разным странам и слава о нём распространится по всему свету. Однако умрёт он на родине от черепа своего любимого коня Факси. Чтобы избежать предначертанного Одд убил коня, бросил его в яму (или болото) и завалил камнями. Герой побывал после этого во многих странах, был, в том числе и на Руси. Умер Одд, как и предсказывала вещунья на родине. Осматривая места своей молодости, он увидел конский череп и сразу понял, что это останки его любимого Факси, ударил его копьём, оттуда выползла змея, укусила его, он разболелся и умер [14, с. 263-267].

По мнению А.И. Лященко, подробно рассмотревшего оба источника, летописец, описывая жизнь и подвиги Олега, использовал предание викингов, а норвежец Одд и есть наш летописный Олег [14, с. 269, 270]. И.Н. Данилевский менее категоричен. Он отмечает, что «направленность» совпадений скандинавской саги и русской летописи не ясна (то есть, кто у кого заимствовал сюжет непонятно). Это затрудняет понимание летописного рассказа о смерти Олега [3, с. 121].

Выходит, что ни одно из описанных летописцами событий, связанных с именем Олега, не находит подтверждения в других источниках. Все они являются результатом книжных построений, основанных на библейских и фольклорных сюжетах, с использованием стереотипов поведения князей современных летописям. Иначе говоря, Олег в «Повести временных лет» делает только то, что должен был делать, согласно представлениям людей XI-XII веков. В силу этого, говорить о том, что Вещий Олег является первым достоверным правителем Руси не приходится.

Кроме русских летописей, Олег известен только од- ному источнику - так называемому «Кембриджскому документу». Здесь он называется царём Руси. Олег (Х-лгу), по данным документа, действовал во времена князя Игоря и императора Византии Романа Лакапина, то есть несколько позже летописного героя. По наущению императора ромеев Олег напал на хазар и захватил Тмутаракань (С-м-к-раю). Но после этого потерпел поражение от хазарского военачальника Песаха и вынужден был воевать уже с Византией. Обстоятельства похода на греков, описанные в документе, напоминают поход Игоря 941 года. Будучи разгромленным греками, которые одолели его «огнём», Олег не вернулся на родину. Он пошёл морем в Персию и там погиб [9, с. 181-183].

Исходя из всего вышесказанного, сообщение Новгородской Первой летописи о том, что Олег был воеводой Игоря, а не князем, мне кажется, более вероятным. Предпочтение, отдаваемое «Повести», опирается главным образом на данные договора 911 года. Считается, что автор «Повести временных лет», обнаружив имя Олега в договоре, где он называется князем, исправил своего предшественника и заодно поправил хронологию событий. Учитывая, что имя Олега могло попасть в договор благодаря стараниям самого летописца, этот аргумент в пользу данных «Повести» может быть отвергнут. Скорее всего, Олег был воеводой. Подобно Свенельду, он имел немало власти и воспринимался некоторыми иностранными авторами, не сведущими в особенностях русской политической системы, как царь. Учитывая сведения «Кембриджского документа», можно полагать, что Олег участвовал в походе Игоря на Царьград в 941 году, а потом ушёл на Каспий, где и погиб, дав основания для возникновения легенды о гибели за морем от укуса змеи. Какой-то Олег в Киеве действительно жил, может быть даже не один (если иметь в виду две могилы Олега - на Щековице и у Жидовских ворот). Однако тот летописный образ, который был нарисован автором «Повести» вряд ли имеет к нему отношение. Летописный Олег - плод творчества древнерусского книжника, а не историческое лицо.

\section{ЛИТЕРАТУРА}

1. Барац Г.М. Критико-сравнительный анализ договоров Руси с Византией. Киев: Типография 1-й киевской артели печатного дела, 1910.266 с.

2. Греков Б.Д. Киевская Русь. М.: 000 «Издательство АСТ», 2004. 671 с.

3. Данилевский И.Н. Повесть временных лет: герменевтические основы источниковедения летописных текстов. М.: Аспект-Пресс, 2004. 370 с.

4. Даркевич В.П. Происхождение и развитие городов Древней Руси (Х - ХІІІ вВ.) // Вопросы истории. 1994. №10. С.43 - 60.

5. Добровольский Д.А. Эсхатологические мотивы В самоидентификации древнерусских летописцев XІ-ХІІ Вв. // Вестник РГГУ. 2008. № 4. С. 148-156.

6. Древняя Русь. Город, замок, село / отв. ред. Б. А. Колчин. М.: Наука, 1985. 431 с.

7. Дубов И.В. Города, величеством сияющие. Л.: Изд-во ЛГУ, 1985. 182 с.

8. Каштанов С.М. Из истории русского средневекового источника (Акты X-XVI вв.). М.: Наука, 1996. 265 С.

9. Кембриджский документ // Древняя Русь в свете зарубежных источников. Т. 3. Восточные источники / сост. Ч. 1. Т. М. Калинина, И. Г. Коновалова; Ч. 2. В.Я. Петрухин. М.: Русский Фонд Содействию Образованию и Науке, 2009. С. 178-184. 
10. Ключевский В.0. Русская история. Полный курс лекций в 3-х кн. М.: Мысль, 1995. Т. 1. 572 с.

11. Котляр Н.Ф. Древнерусская государственность. СПб.: Алетейя, 1998. 446 с.

12. Культура Византии. Вторая половина VII-XII в. / Отв. ред. З.В. Удальцова, Г.Г. Литаврин. М.: Наука, 1989. 680 с.

13. Ламбин Н.П. Поход Олега под Царьград — сказка ли? // Журнал Министерства народного просвещения. 1873. № 7. С. 115-127.

14. Лященко А.И. Летописные сказания о смерти Олега Вещего // Известия Отд. рус. яз. и словесности. 1924. Т. 29. С. $254-288$.

15. Мавродин В.В. Образование древнерусского государства. Л.: Изд-во ЛГУ, 1945. 432 с.

16. Никитин А.Л. Основания русской истории: Мифологемы и факты. М.: «Аграф», 2001.768 с.

17. Новосельцев А.П. Образование древнерусского государства и первый его правитель // Вопросы истории. 1991. №2-3. С. 3-20.

18. Очерки истории СССР. В 9 т. Т. 3. Период феодализма в 2-х ч. Ч. 1. IX-XIII вВ. Древняя Русь. Феодальная раздробленность / Гл. ред. акад. Б.Д. Греков (пред.) [и др.]. М.: Изд-во Акад. наук СССР, 1953. 984 с.

19. Платонов С.Ф. Лекции по русской истории. Петрозаводск: АО «Фолиум», 1996.838 с.

20. Повесть временных лет / подготовка текста, перевод, статьи и комментарии Д.С. Лихачёва / под ред. В.П. Адриановой-Перетц. Изд. 2-е, испр. и доп. СПб.: Наука, 1996. 668 с.

21. ПСРЛ. Т. 1. Лаврентьевская летопись. М.: Языки русской культуры, 1997. 496 с.

22. ПСРЛ. Т. 3. Новгородская первая летопись старшего и младшего изводов. М.: Языки русской культуры, 2000. 720 с.

23. ПСРЛ. Т. 37. Устюжские и Вологодские летописи XVI-XVIII вв. Л.: Наука, Ленинградское отделение, 1982. 228 с.

24. Сага 06 Одде Стреле // Древняя Русь в свете зарубежных источников. Т. 5. Древнескандинавские источники / сост. Ч. I, II, XII E.А. Мельникова; Ч. III, IV, V, VII, VIII, XI T. Н. Джаксон; Ч. VI, IX, X Г.В. Глазырина. М.: Русский Фонд Содействию Образованию и Науке, 2009. С. 259-266.

25. Саксон Грамматик. Деяния данов / подгот. изд. А.С. Досаев, И.А. Настенко. М.: «Русская панорама», 2017. Т. 1. 608 с.

26. Татищев В.Н. История Российская: в 3 т. М.: АСТ: Ермак, 2005. Т.1. 568 с.

27. Юшков С.В. Курс истории государства и права СССР. Т. 1. Общественно-политический строй и право Киевского государства. М.: Госиздат. Юридическая литература, 1949.543 C.

28. Янин В.Л. Я послал тебе бересту. 3-е изд. М.: Языки русской культуры, 1998. 464 с.

(c) Поляков Александр Николаевич (polyakov150@mail.ru).

Журнал «Современная наука: актуальные проблемы теории и практики»

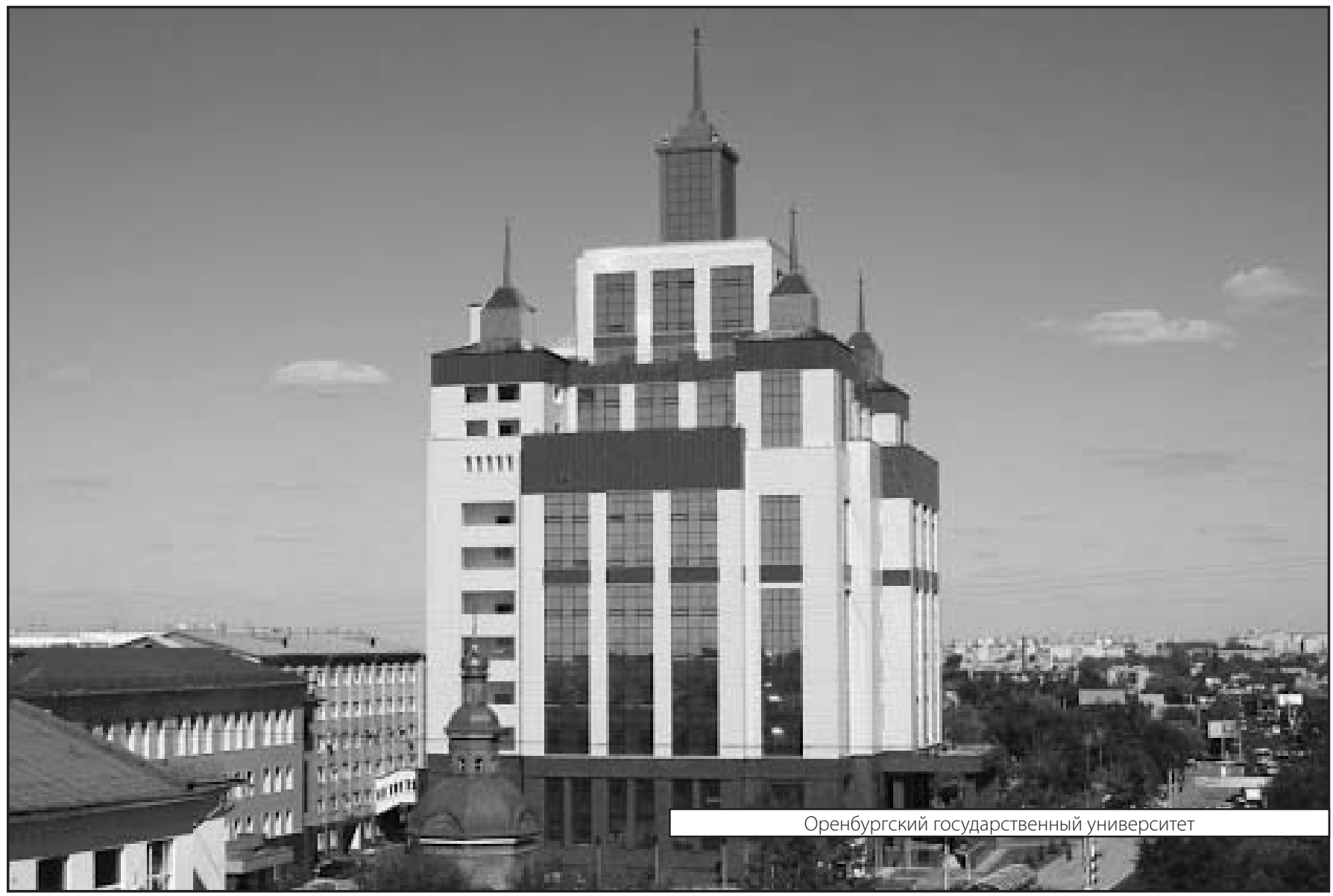

